research support from: Novartis, Pfizer, Grant/research support from: Novartis, Pfizer, Consultant for: AbbVie, Bristol-Myers Squibb, Celgene, Corrona, Eli Lilly and Company, Novartis, Pfizer, and Takeda, Consultant for: AbbVie, Amgen, Bristol-Myers Squibb, Celgene, Corrona, Eli Lilly, Novartis, Pfizer Inc, Takeda, Consultant for: Abbvie, Amgen, BMS, Celgene, Corrona, Lilly, Novartis, Pfizer, Takeda, Consultant for: Abbvie, Amgen, BMS, Celgene, Corrona, Lilly, Novartis, Pfizer, Takeda DOI: 10.1136/annrheumdis-2019-eular.1659

\section{SAT0396 IMPROVEMENT IN THE SIGNS AND SYMPTOMS OF PSORIATIC ARTHRITIS WITH IXEKIZUMAB COMPARED TO PLACEBO IN PATIENT SUBGROUPS DEFINED BY BASELINE DISEASE CHARACTERISTICS}

Hans-Peter Tony ${ }^{1}$, Eva Galindez ${ }^{2}$, Aubrey Trevelin Sprabery ${ }^{3}$, Amanda M. Gellett ${ }^{3}$, Chen-Yen Lin ${ }^{3}$, So Young Park ${ }^{3}$, Clinton C. Bertram ${ }^{3}$, Alexis Ogdie ${ }^{4} .{ }^{1}$ University Hospital of Würzburg, Würzburg, Germany; ${ }^{2}$ Hospital de Basurto, Billbao, Spain; ${ }^{3}$ Eli Lilly and Company, Indianapolis, United States of America; ${ }^{4}$ Penn Medicine, Philadelphia, United States of America

Background: Ixekizumab (IXE), a high-affinity monoclonal antibody that selectively targets interleukin-17A, was superior to placebo (PBO) in two randomized Phase 3 studies in patients (pts) with active psoriatic arthritis (PsA). ${ }^{1,2}$

Objectives: To assess the consistency of response of IXE across subgroups of pts defined by specific baseline disease characteristics.

Methods: Data were analyzed from an integrated database of 2 randomized, double-blind, Phase 3 studies in pts who were either biologic Disease Modifying Anti-Rheumatic Drug (bDMARD)-naïve (SPIRIT-P1) or who had prior inadequate response or intolerance to TNF inhibitors (SPIRITP2). Analyses included pts randomly assigned to the approved dosing regimen of IXE (80 mg IXE every 4 wks [IXE Q4W] with a starting dose of $160 \mathrm{mg}$ IXE) or to PBO through Wk 24. Efficacy was measured as the percentage of pts achieving $\geq 20 \%, 50 \%$, or $70 \%$ improvement from baseline in the American College of Rheumatology criteria (ACR20/50/70) or minimal disease activity (MDA) in subgroups of pts defined by baseline presence of enthesitis, dactylitis, psoriasis body surface area (BSA) involvement $(<3 \%$ or $\geq 3 \%$ ), and c-reactive protein (CRP $>6$ or $\leq 6 \mathrm{mg} / \mathrm{L}$ ). Missing data were imputed by nonresponder imputation.

Results: Clinical response rates at Wk 24 in each subgroup are summarized (Table). Significantly $(\mathrm{p}<0.05)$ more patients achieved ACR20, ACR50, ACR70, and MDA with IXE compared to placebo across patient subgroups defined by presence of enthesitis, presence of dactylitis, percentage of psoriasis BSA involvement, and by CRP levels at baseline. Conclusion: At Wk 24, IXE was superior to placebo for the treatment of PsA signs and symptoms regardless of baseline presence of dactylitis or enthesitis, BSA involvement, or CRP levels.

\section{REFERENCES}

[1] Mease, et al. Ann Rheum Dis. 2017

[2] Nash, et al. Lancet. 2017
Disclosure of Interests: Hans-Peter Tony Consultant for: Eli Lilly and Company, Speakers bureau: Eli Lilly and Company, Eva Galindez: None declared, Aubrey Trevelin Sprabery Shareholder of: Eli Lilly and Company, Employee of: Eli Lilly and Company, Amanda M. Gellett Shareholder of: Eli Lilly and Company, Employee of: Eli Lilly and Company, Chen-Yen Lin Shareholder of: Eli Lilly and Company, Employee of: Eli Lilly and Company, So Young Park Employee of: Eli Lilly and Company, Clinton C Bertram Shareholder of: Eli Lilly and Company, Employee of: Eli Lilly and Company, Alexis Ogdie Grant/research support from: (To my university) Novartis, Pfizer, Grant/research support from: Novartis, Pfizer, Grant/research support from: Novartis, Pfizer, Grant/research support from: Novartis, Pfizer, Consultant for: AbbVie, Bristol-Myers Squibb, Celgene, Corrona, Eli Lilly and Company, Novartis, Pfizer, and Takeda, Consultant for: AbbVie, Amgen, Bristol-Myers Squibb, Celgene, Corrona, Eli Lilly, Novartis, Pfizer Inc, Takeda, Consultant for: Abbvie, Amgen, BMS, Celgene, Corrona, Lilly, Novartis, Pfizer, Takeda, Consultant for: Abbvie, Amgen, BMS, Celgene, Corrona, Lilly, Novartis, Pfizer, Takeda

DOI: 10.1136/annrheumdis-2019-eular.1620

\section{SAT0397 DESCRIPTIVE COMPARISONS OF THE IMPACT OF APREMILAST AND METHOTREXATE MONOTHERAPY ON PATIENTS WITH OLIGOARTICULAR PSORIATIC ARTHRITIS IN THE CORRONA PSORIATIC ARTHRITIS/ SPONDYLOARTHRITIS REGISTRY}

Alexis Ogdie $^{1}$, Mei Liu ${ }^{2}$, Meghan Glynn², Kelechi Emeanuru², Leslie Harrold ${ }^{2,3}$, Sven Richter ${ }^{4}$, Benoit Guerette ${ }^{4}$, Philip J. Mease ${ }^{5}$. ${ }^{1}$ University of Pennsylvania, Philadelphia, United States of America; ${ }^{2}$ Corrona, LLC, Waltham, United States of America; ${ }^{3}$ University of Massachusetts Medical School, Worcester, United States of America; ${ }^{4}$ Celgene Corporation, Summit, United States of America; ${ }^{5}$ Swedish Medical Center and University of Washington School of Medicine, Seattle, United States of America

Background: Therapeutic effectiveness has rarely been studied in a subpopulation of patients with oligoarticular PsA

Objectives: To examine baseline characteristics and 6-month clinical assessments of PsA patients with oligoarthritis ( $\leq 4$ swollen joints) who initiated apremilast (APR) or methotrexate (MTX) monotherapy in the Corrona PsA/SpA Registry, a prospective, US-based, observational cohort study. Patients initiating bDMARD monotherapy were also examined as a point of reference.

Methods: Patients $\geq 18$ years of age with PsA and oligoarthritis in the registry who initiated APR, MTX or a bDMARD (reference group) monotherapy and had a 6-month follow-up visit between June 2014 and March 2018 were included. Descriptive statistics were calculated for patients' clinical characteristics and disease assessments at treatment initiation and at the 6-month follow-up visit.

Results: The analysis included 150 patients initiating therapy (APR: $\mathrm{n}=34$; MTX: $\mathrm{n}=15$; bDMARD: $\mathrm{n}=101$ ). Among APR and MTX initiators $79 \%$ and $20 \%$ received at least 1 prior bDMARD, respectively. APR initiators, compared with MTX initiators, were younger (mean [SD]: 55.7 [12.6] vs. 61.5 [16.6] years), had longer disease duration (mean [SD]: 8.0 [6.7] vs. 5.4 [7.8] years), and had higher levels of disease activity

\begin{tabular}{|c|c|c|c|c|c|c|c|c|}
\hline \multicolumn{9}{|c|}{ Clinical responses at Week 24 in subgroups defined by baseline disease characteristics (NRI) } \\
\hline & \multicolumn{2}{|c|}{ ACR20 } & \multicolumn{2}{|c|}{ ACR50 } & \multicolumn{2}{|c|}{ ACR70 } & \multicolumn{2}{|c|}{ MDA } \\
\hline & $\begin{array}{c}\text { PBO } \\
\text { (N=224) }\end{array}$ & $\begin{array}{c}\text { IXE Q4W } \\
(\mathrm{N}=229)\end{array}$ & $\begin{array}{c}\text { PBO } \\
(\mathrm{N}=224)\end{array}$ & $\begin{array}{c}\text { IXE Q4W } \\
(\mathrm{N}=229)\end{array}$ & $\begin{array}{c}\mathrm{PBO} \\
(\mathrm{N}=224)\end{array}$ & $\begin{array}{c}\text { IXE Q4W } \\
(\mathrm{N}=229)\end{array}$ & $\begin{array}{c}\text { PBO } \\
(\mathrm{N}=224)\end{array}$ & $\begin{array}{r}\text { IXE Q4Y } \\
(\mathrm{N}=229)\end{array}$ \\
\hline $\begin{array}{l}\text { Enthesitis } \\
\text { Present }\end{array}$ & 29/142 (20) & $\begin{array}{c}88 / 159 \\
(55) \div\end{array}$ & 12/142 (9) & $58 / 159(37) \dagger$ & $\begin{array}{c}2 / 142 \\
(1)\end{array}$ & $31 / 159(20) \dagger$ & $\begin{array}{c}6 / 142 \\
(4)\end{array}$ & $\begin{array}{c}41 / 159 \\
(26) \dagger\end{array}$ \\
\hline Enthesitis Absent & $26 / 81(32)$ & $39 / 70(56) \neq$ & 10/81 (12) & $28 / 70(40) \dagger$ & $\begin{array}{l}4 / 81 \\
(5)\end{array}$ & $21 / 70(30) \dagger$ & $14 / 81(17)$ & $\begin{array}{l}25 / 70 \\
(36)^{*}\end{array}$ \\
\hline Dactylitis Present & 12/59 (20) & $55 / 92(60) \dagger$ & $\begin{array}{l}6 / 59 \\
(10)\end{array}$ & $38 / 92(41) \dagger$ & $\begin{array}{c}2 / 59 \\
(3)\end{array}$ & $24 / 92(26) \dagger$ & $\begin{array}{c}5 / 59 \\
(9)\end{array}$ & $\begin{array}{l}33 / 92 \\
(36) \dagger\end{array}$ \\
\hline Dactylitis Absent & 43/164 (26) & $72 / 137(53) \dagger$ & 16/164 (10) & $48 / 137(35) \dagger$ & $\begin{array}{c}4 / 164 \\
(2)\end{array}$ & $28 / 137(20) \dagger$ & 15/164 (9) & $\begin{array}{c}33 / 137 \\
(24) \dagger\end{array}$ \\
\hline BSA $<3 \%$ & 20/85 (24) & $44 / 80(55) \dagger$ & $\begin{array}{c}8 / 85 \\
(9)\end{array}$ & $29 / 80(36) \dagger$ & $\begin{array}{l}2 / 85 \\
(2)\end{array}$ & $17 / 80(21) \dagger$ & $\begin{array}{c}6 / 85 \\
(7)\end{array}$ & $\begin{array}{l}21 / 80 \\
(26) \$\end{array}$ \\
\hline BSA $\geq 3 \%$ & $35 / 134(26)$ & $77 / 141(55) \dagger$ & 14/134 (10) & $55 / 141(39) \dagger$ & $\begin{array}{c}4 / 134 \\
(3)\end{array}$ & $34 / 141(24) \dagger$ & 13/134(10) & $\begin{array}{c}42 / 141 \\
(30) \dagger\end{array}$ \\
\hline $\mathrm{CRP} \leq 6 \mathrm{mg} / \mathrm{L}$ & 29/100 (29) & $45 / 97(46)^{*}$ & 11/100 (11) & $31 / 97(32) \dagger$ & $\begin{array}{l}2 / 100 \\
(2)\end{array}$ & $16 / 97(17) \dagger$ & $11 / 100(11)$ & $\begin{array}{l}25 / 97 \\
(26) \$\end{array}$ \\
\hline CRP $>6$ mg/L & 26/122 (21) & $80 / 129(62) \dagger$ & 11/122 (9) & $54 / 129(42) \dagger$ & $\begin{array}{c}4 / 122 \\
(3)\end{array}$ & $36 / 129(28) \dagger$ & $\begin{array}{c}9 / 122 \\
(7)\end{array}$ & $\begin{array}{c}41 / 129 \\
(32) \dagger\end{array}$ \\
\hline
\end{tabular}

Data are provided as $\mathrm{n} / \mathrm{Ns}(\%)$ where $\mathrm{n}=$ number of responders and $\mathrm{Ns}=$ number of patients in each subgroup $\mathrm{p}$-values from Fisher's exact test; ${ }^{*}=\mathrm{p}<0.05$, $t=\mathrm{p}<0.01,+=\mathrm{p}<0.001$ ACR20/50/70 $=\geq 20 \%, 50 \%$, or $70 \%$ improvement from baseline in the American College of Rheumatology criteria; $B S A=$ body surface area; CRP $=\mathrm{c}$-reactive protein; IXE Q4W $=80$ mg IXE every 4 weeks; $\mathrm{MDA}=$ minimal disease activity; $\mathrm{PBO}=$ placebo 
at baseline, including greater skin involvement (mean body surface area affected [SD]: $7.1 \%[17.6 \%]$ vs. $4.8 \%$ [9.4\%]), swollen joint count (mean [SD]: 1.5 [1.5] vs. 1.0 [1.1]) and Clinical Disease Activity for Psoriatic Arthritis (cDAPSA) moderate and high disease activity (50\% [APR] vs. 27\% [MTX]; mean score [SD]: 14.0 [8.5] vs. 11.5 [4.9]). APR initiators also had greater disease impairments at baseline, represented by numerically higher scores on patient-reported outcome (PRO) measures, including the Health Assessment Questionnaire-Disability Index (HAQ-DI; mean [SD]: 1.0 [0.7] vs. 0.5 [0.4]), Patient's Global Assessment of Disease Activity-Psoriasis (PtGA-PsO; mean [SD]: 47.1 [29.4] vs. 28.4 [16.6]); Patient's Global Assessment of Disease Activity-Psoriatic Arthritis (PtGA-PsA; mean [SD]: 47.1 [29.8] vs. 32.5 [26.3]), fatigue (mean [SD]: 55.9 [30.0] vs. 37.8 [31.9]) and overall pain (mean [SD]: 50.5 [31.1] vs. 46.7 [26.5]). Taken together, results suggest that APR initiators had more refractory oligoarthritis compared with MTX initiators. Clinical assessments at the 6-month follow-up indicate that patients who initiated APR experienced numerically higher improvements in disease activity and various PRO measures compared with MTX, as well as achievement of $\leq 1$ swollen joint, HAQ-DI minimal clinically important difference and cDAPSA remission or low disease activity (Table). Of note, results associated with bDMARDs were more comparable to that of APR.

Conclusion: In this analysis of the Corrona PsA/SpA Registry, APR monotherapy was more often used in patients with refractory oligoarthritis compared with MTX monotherapy. Despite this, the APR treatment group experienced numerically greater improvements in disease activity measures. Improvements observed with APR treatment in patients with longstanding disease and refractory oligoarthritis were comparable to that of bDMARDs.

\begin{tabular}{|c|c|c|c|}
\hline \multicolumn{4}{|c|}{$\begin{array}{l}\text { Clinical Disease Assessments of Corrona PsA/SpA Registry } \\
\text { Patients With Oligoarthritis at the 6-Month Visit }\end{array}$} \\
\hline Disease Characteristics & $\begin{array}{l}\text { APR } \\
n=34\end{array}$ & $\begin{array}{l}\text { MTX } \\
n=15\end{array}$ & $\begin{array}{c}\text { DDMARD } \\
\mathrm{n}=101\end{array}$ \\
\hline Swollen joint count (0-66) & $n=34$ & $n=15$ & $n=101$ \\
\hline Mean (SD) change & $-0.4(1.2)$ & $0.1(0.4)$ & $0.2(1.4)$ \\
\hline Achieved swollen joint count $(0-66) \leq 1^{*}$ & $\mathrm{n}=17$ & $n=4$ & $\mathrm{n}=26$ \\
\hline & $7(41.2)$ & $0(0.0)$ & $4(15.4)$ \\
\hline CDAPSA $(0-154)$ & $n=32$ & $\mathrm{n}=11$ & $n=96$ \\
\hline Mean (SD) change & $-1.5(5.8)$ & $-0.2(1.9)$ & $-0.1(6.8)$ \\
\hline CDAPSA category, $n(\%)$ & $\begin{array}{c}-1.35 .06) \\
n=17\end{array}$ & $n=3$ & $n=36$ \\
\hline Remission ( $\leq 4)$ & $1(5.9)$ & $0(0.0)$ & $2(5.6)$ \\
\hline Low disease activity (>4- $\leq 13$ ) & $4(23.5)$ & $0(0.0)$ & $6(16.7)$ \\
\hline PtGA-PSO (VAS 0-100 mm) & $n=34$ & $\mathrm{n}=11$ & $n=97$ \\
\hline Mean (SD) change & $-2.3(22.1)$ & $1.7(10.1)$ & $-2.0(27.4)$ \\
\hline PtGA-PsA (VAS 0-100 mm) & $n=34$ & $\mathrm{n}=13$ & $n=97$ \\
\hline Mean (SD) change & $-0.2(23.8)$ & $2.5(13.9)$ & $0.4(25.0)$ \\
\hline Patient-reported fatigue (VAS 0-100 mm) & $n=33$ & $n=15$ & $n=100$ \\
\hline Mean (SD) change & $-1.4(15.7)$ & $0.3(30.2)$ & $-0.3(20.1)$ \\
\hline Patient-reported overall pain (VAS 0-100 mm) & $n=32$ & $n=14$ & $n=99$ \\
\hline Mean (SD) change & $0.2(26.3)$ & $-0.1(15.6)$ & $0.1(20.4)$ \\
\hline Achieved HAQ-DI MCID ( 20.35 point decrease) & $n=34$ & $n=14$ & $\mathrm{n}=100$ \\
\hline $\mathrm{n}(\%)$ & $4(11.8)$ & $1(7.1)$ & $8(8.0)$ \\
\hline
\end{tabular}

visit value misus the baseline value MCID=minime of treatment initiation. Change at 6 months was calculect

Acknowledgement: This study was sponsored by Corrona, LLC. Corrona is supported through contracted subscriptions with multiple pharmaceutical companies. The abstract was a collaborative effort between Corrona and Celgene Corporation with financial support provided by Celgene.

Disclosure of Interests: Alexis Ogdie Grant/research support from: (To my university) Novartis, Pfizer, Grant/research support from: Novartis, Pfizer, Grant/research support from: Novartis, Pfizer, Grant/research support from: Novartis, Pfizer, Consultant for: AbbVie, Bristol-Myers Squibb, Celgene, Corrona, Eli Lilly and Company, Novartis, Pfizer, and Takeda, Consultant for: AbbVie, Amgen, Bristol-Myers Squibb, Celgene, Corrona, Eli Lilly, Novartis, Pfizer Inc, Takeda, Consultant for: Abbvie, Amgen, BMS, Celgene, Corrona, Lilly, Novartis, Pfizer, Takeda, Consultant for: Abbvie, Amgen, BMS, Celgene, Corrona, Lilly, Novartis, Pfizer, Takeda, Mei Liu Employee of: M. Liu is an employee of Corrona, LLC., Meghan Glynn Employee of: M. Glynn is an employee of Corrona, LLC., Kelechi Emeanuru Employee of: Corrona, LLC, Leslie Harrold Shareholder of: Corrona, Grant/research support from: Pfizer, Consultant for: AbbVie, BMS, and Genentech, Employee of: Corrona, Sven Richter Employee of: Celgene Corporation, Benoit Guerette Employee of: Celgene Corporation, Philip J Mease Grant/research support from: AbbVie, Amgen, BMS, Celgene, Janssen, Lilly, Novartis, Pfizer, SUN and UCB, Consultant for: AbbVie, Amgen, BMS, Galapagos, Gilead Sciences, Inc., Janssen, Lilly, Novartis, Pfizer, SUN and UCB, Speakers bureau: AbbVie, Amgen, BMS, Celgene, Genentech, Janssen, Lilly, Novartis, Pfizer and UCB

DOI: 10.1136/annrheumdis-2019-eular.779

\section{SAT0398 EVALUATION OF THE PREDICTIVITY OF THE THERAPEUTIC RESPONSE ACCORDING TO THE PRESENCE OF METABOLIC COMORBILITIES IN PATIENTS WITH PSORIASIC ARTHRITIS ON BIOTECHNOLOGY THERAPY: OBSERVATIONAL RETROSPECTIVE STUDY}

Simone Parisi ${ }^{1}$, Davide Mohammad Reza Beigi ${ }^{1}$, Marta Priora ${ }^{1}$, Maria Chiara Ditto ${ }^{1}$, Clara Lisa Peroni ${ }^{1}$, Angela Laganà ${ }^{1}$, Enrico Fusaro ${ }^{1}{ }^{1}$ A.O.U. Città della Salute e della Scienza, Rheumatology, Turin, Italy

Background Psoriatic Arthritis (PsA) is a systemic chronic inflammatory disease, which leads to an increased oxidative stress and to endothelial alterations, with increased cardiovascular and metabolic risks. These conditions explain the high prevalence of myocardial infarction, cerebrovascular accidents, diabetes mellitus, obesity, steatohepatitis, alterations of lipid set and an increased prevalence of metabolic syndrome in patients with PsA. The results of other studies suggest that these comorbidities could negatively influence the disease activity and the therapy response in patients with PsA.

Objectives The aim of the study is to evaluate a population of patients with PsA treated with biological drugs (bDMARDs) and the achievement of MDA during the observation.

Methods Ninety-eight patients with PsA treatd by DMARDs from January 2016 to January 2018 were enrolled. Data were collected for 24 months of treatment, related to the check-ups performed every three months. Demographic characteristics, cardiovascular risk factors and cardio-metabolic comorbidities, disease joint involvement at baseline and the assumed therapy were analyzed. The association with the presence of MDA at 0 months and 24 months was evaluated for each of these parameters. Age and gender of patients, duration of illness and smoking habits were taken into consideration. Cardio-vascular risk factors and cardio-metabolic comorbidities selected at baseline were arterial hypertension, diabetes, obesity, hepatic steatosis, hypercholesterolemia, hypertriglyceridaemia, hyperuricaemia, cardiac disorders (myocardial infarction and atrial fibrillation) and cerebro-vascular accidents (stroke and TIA). The population was subdivided according to oligoarticular or polyarticular involvement of the disease present at baseline. As far as the therapy carried out is concerned, the patients were classified according to the class of bDMARDs (anti-TNF- $\alpha$ and not anti-TNF- $\alpha$ ), the treatment line at the beginning of the observation (first line or second line and subsequent), the number of switches at 12 and 24 months and simultaneous therapy with relative average dose of drugs (methotrexate and glucocorticoids).

Results Male sex was more associated with the condition of MDA, both at baseline $(p=0.01)$ and at 24 months $(p=0.04)$. A statistically significant association between the presence of cerebro-vascular accidents (stroke and TIA) and the disease status was found at baseline: amongst patients with such comorbidity, $75 \%$ were not found in MDA at time 0 ( $p$ $=0.03)$. The same result was not found in relation to MDA after 24 months. No other cardio-metabolic comorbidity was associated with a worse outcome. There was no association with a better outcome for any of the two classes of biological drugs considered (anti-TNF- $\alpha$ and not anti-TNF- $\alpha$ ). Polyarticular involvement was associated with a worse disease status, both at baseline $(p=0.01)$ and after 24 months of therapy $(\mathrm{p}=0.04)$.

Conclusion In the current study, the polyarticular form of PsA present at baseline was the most associated feature (OR 0.44) with a worse outcome in a population of patients with cardio-metabolic comorbidities on bDMARDs. Cerebro-vascular accidents appeared as the only morbid condition associated with a worse state of disease at the beginning of the observation, but this correlation disappears after 24 months. This result can be justified by the immunosuppressive treatment, which decreases the risks related to the inflammatory condition characteristic of PsA.

Disclosure of Interests Simone Parisi Speakers bureau: Chiesi, Jansenn, Pfizer, Celgene, Abbvie, Lilly., Davide Mohammad Reza Beigi: None declared, Marta Priora Grant/research support from: Sanofi SpA, Maria Chiara Ditto: None declared, Clara Lisa Peroni: None declared, Angela Laganà: None declared, Enrico Fusaro Grant/research support from: Abbvie, Abiogen, Actelion, Amgen, Biogen, BMS, Celgene, Grunenthal, GSK, Janssen, Lilly, MSD, Mundipharma, Novartis, Pfizer, Roche, SANOFI, SOBI, UCB

DOI: 10.1136/annrheumdis-2019-eular.3754 